\title{
SOME METHODS OF TEACHING ENGLISH VIA ONLINE LEARNING SYSTEM USED BY LECTURERS; A DESCRIPTIVE STUDY
}

\author{
Juliansyah $^{1}$, Fajriyati Jamaliyah ${ }^{2}$, Ayu Yohana Setyaningrum ${ }^{3}$ \\ Darma Persada University, Jakarta, Indonesia \\ Darma Persada University, Jakarta, Indonesia \\ Darma Persada University, Jakarta, Indonesia \\ Author corresponding email: \\ ian.juliansyah@gmail.com, fajriyatij@gmail.com, matthewskypers@gmail.com
}

Submitted: $23 / 06 / 2021$

Accepted: 27/July/2021

Publication: 3/August/2021

\begin{abstract}
Firstly, the research aims to know what lecturers use methods of teaching English via an Online Learning System. Secondly, the activities both the lecturers and students have during the learning process. This research is limited to what methods the lecturers apply in teaching English for English department students via an online learning system to build students' enthusiasm for learning. The process of research used is qualitative research. In collecting data, the researcher used observation. There are 8 respondents in this research. They are all lecturers teaching in English Department. The result shows that the lecturers use applications in teaching English, namely Google Classroom, Google Meet, Zoom, and the Learning Management System (LMS) of Darma Persada University, namely portal.unsada.ac.id. The latest application is an official site that lecturers and students use to proceed with the teaching-learning process. The research also finds that lecturers do several activities in the learning process. They fill in the blank, read aloud, answer questions, picture describing, drilling, and presentation techniques. The research shows that those all activities are the most suitable with learning system using online. Meanwhile, in terms of teaching techniques, most of the lecturers use communicative language teaching, grammar-translation, and audio-lingual method.
\end{abstract}

Key words: teaching, Online System, techniques, method, problems.

\section{Introduction}

Learning English is one object that still requires improvements in the learning process. English is still a second language after the mother-tongue for people who do not speak English since birth. By having the ability to speak English, we can easily access and obtain information for most of that information written in English. This happens because English works as the language of science, technology, and commerce.

In English language teaching, an aspect that becomes one of the most important is the method of teaching. Some people say that the method is not so important in learning English, what is important is the willingness to learn, and the quality of the student, while the method is merely a tool. However, regardless of agreement or disagreement on the importance of the method, the fact remains that if there is a lack of success in learning, the teachers are required to review the method that they have used.

Most educational institutions have been using online learning method or known as Elearning for the last 5 years. The learning system is implemented through a computer or laptop connected to an internet connection. Some people consider that online learning requires higher level of self-motivation from students. If students feel bored, they become less enthusiastic in learning online. 
Teachers expect to be able to apply the appropriate learning method to accelerate the process of learning English. Lecturers must be sure to use the best teaching method, so students can understand the subject better and still keep their enthusiasm in learning via online system. Yet, it seems that finding the best method is still far away from reality. The online system of learning is still boring for some students. The lecturers are also confused to find out any better method of teaching.

Based on those situation described above, therefore, we are interested in discussing the methods used by lecturers in teaching English via Online Learning System. This study is an attempt to examine the use of several methods of teaching English via Online Learning System by lecturers at Darma Persada University. In addition, this research also focuses on the topic of what media that most English lecturers use in teaching English through the online system.

\section{Literature Review}

\section{Teaching method}

A method is one of the strategies used by teachers in the teaching and learning process. Iskandar and Sunedar (2008:40) define a method as a procedure to achieve predetermined goals. The teaching method is a tool to achieve teaching goals; the better the use of teaching methods, the more successful it will be to achieve these goals. If the teachers can choose the appropriate method according to the teaching materials, students, conditions, and learning media, the teachers can achieve teaching objectives successfully (Sutomo, 1993: 155).

Certain methods are used in teaching foreign languages at educational institutions. The teaching of foreign languages has developed in line with the people's need for the importance of language skills in the era of globalization, especially mastering English which is an international language. English becomes the most popular language used around the world to communicate with people from different backgrounds. Crystal (1997) and Kaplan (2001) mention that English becomes a "global language" because it becomes a mother tongue, second language, or foreign language in the world.

\section{Teaching purposes}

The purpose of learning English is that students can communicate in English orally and in writing fluently and following their social context (Depdiknas, 2003: 15). Students' English competencies include skills: listening, reading, speaking, and writing. Listening skill means understanding the various meanings (interpersonal, opinions, textbooks) of various oral texts that have specific communicative, text structure, and linguistic objectives. Meanwhile, speaking skill refers to the ability to express various meanings (between individuals, opinions, textbooks) through various oral texts that have specific communicative, text structure, and linguistic objectives. Reading means understanding various meanings (interpersonal, opinions, textbooks) in various written texts that have specific communicative, text structure, and linguistic objectives. Writing means revealing various meanings (interpersonal, opinion, textbook) in various written texts that have communicative purposes, text structure, and certain linguistics.

\section{E-learning system}

Foreign language learning system has changed along with technological advances. These days, learning is no longer using classrooms or laboratories but is more technology-based. The online learning system is learning that is conducted online using learning applications and social networks. Chandrawati (2010) defines E-learning system as a distance learning process by combining the principles in the process of learning with technology. Online learning provides an excellent method because it is not bound by time or location in which they allow accessibility to teach anytime and anywhere. Changes in the online learning system have implications for changes in learning methods, perspectives, and even changes in concepts in language learning. Meanwhile, Belawati says online learning is an ordinary learning that is carried out on-line, but the principles of learning that are carried out normally and conventionally still apply (Belawati, 2019). 
In term of the characteristic of using online system, Giatman says that on-line learning is not enough to simply transfer teaching material directly into material that is delivered on-line, but one of the most important things in on-line learning is how lecturers can interact with their students (Giatman et al., 2020, p. 168-175). Similarly, as stated by Dhawan, "It will enhance problem-solving skills, critical thinking abilities, and adaptability among the students. In this critical situation, users of any age can access the online tools and reap the benefits of time and location flexibility associated with online learning" (Dhawan, 2020, p. 15). Finally, according to J. Anderson \& McCormick, 2005, online learning needs to pay attention to several points, namely: (a) compliance with the curriculum, (b) inclusiveness, (c) learners involvement, (d) innovation, (e) learning efficiency, (f) formative and summative evaluation, (g) Coherency, consistency, and transparency, (h) the effectiveness of the device (easy to operate and use), and (i) cost effectiveness.

\section{Other similar researches}

In other similar researches, Pido, Nur Wahidah, and Erliana Dewi (2009: 59) explains that the term method in language learning means comprehensive planning to present language subject matter regularly. This term is more procedural in the sense that the application of a method in language learning is carried out through regular and gradual steps, starting from the preparation of teaching planning, presentation of teaching, teaching and learning processes, and assessment of learning outcomes. Rahim (2006: 22) reveals the characteristic of foreign language teaching is that students must acquire the ability to use it as a means of communication and learn to think in that language. To achieve communicative goals, an appropriate and good approach is needed in the learning process.

\section{Research Method}

This study uses a qualitative research approach. Qualitative research is a research in which researchers do not use statistical methods in collecting data and in providing interpretations of the results. In addition, qualitative research considers the role of the researcher as a key instrument in collecting data and interpreting data. Data collection tool in this study is direct observation and interview.

In the relation to qualitative research, this research does not have a clear time limit until the researcher gets a truly deep understanding of the object under study. However, this research was conducted between December 2020 to January 2021. In connection with this research, we have respondents, namely: 1) Lecturers of English subjects, and 2) Students of English Literature department.

In a research method that adheres to the scientific method, the stages of research must be systematic and procedural or well planned. The stages in this research are as follow:

1. Preparation Stage

At this stage the researchers prepare everything, such as identifying and formulating problems, arranging permission letters, making a list of questions, determining the right informants, conducting interviews and all supporting tools to be used such as interview guides, books and stationery, cameras, and tape recorder. The interview guide contains basic questions that will later develop in the interview.

2. Research Implementation Stage

The researcher made an agreement with the subject regarding the time and place to conduct the interview based on the guidelines made. After we finished doing the interview, we documented the results of the interview. Furthermore, the researchers conducted data analysis and data interpretation and processed the data.

3. Report Preparation Stage

The last stage is to compile a report on the results of the research. We present the categorized data, present research documentation, describe the results of the analysis and make conclusions about the research results. 


\section{Results and Discussion}

Currently, there is a change in the paradigm pattern of language learning because currently teaching and learning activities are carried out by online. Learning is no longer using writing instruments, projectors, or using classrooms and laboratories, but now learning has become more technology-based. These changes in learning have implications for changes in learning methods, perspectives, and even changes in concepts in interpreting existence, principles, and approaches in language learning.

These days, there are lots of media or applications to support teaching and learning activities. Based on the results of observations that have been conducted, we found several applications or media used by Darma Persada University lecturers as follow:

1. Google Classroom

Google classroom is an application used by teachers and students to facilitate learning through on line. This application helps teachers in creating and distributing assignments quickly and shortening the time. As for the students, Google Classroom help them do the assignment more effectively task wherever and whenever. Google Classrooms are free by registering first on the Google account. Students can receive and submit assignments directly in the Classroom as well as teachers.

2. Zoom

The ZOOM application is an application that can be used to facilitate independent learning from home by teachers and students. Teachers can take advantage of various features in the zoom application to interact with students, so this zoom application can greatly assist twoway communication between teachers and students.

3. Google Meet

Google Meet is currently widely used for distance learning in Indonesia. Armed with an internet connection, teachers and students can continue the teaching and learning process even without a face-to-face process.

4. Learning Management System application (portal.unsada.ac.id)

The portal.unsada.ac.id site is a special website created by Darma Persada University. On this website, students can access online classes and also fill in daily attendance using their registered accounts. In addition, this website also contains other academic information, such as exam schedules, vacation and leave schedules, finances, and so on.

Researchers observed lecturers who taught in the English Department of Darma Persada University. From a total of 8 lecturers teaching in a class, the researcher found that the number of lecturers and the application they use as follow:

\begin{tabular}{|l|l|c|}
\hline No. & $\begin{array}{l}\text { Applications and Media Used by Darma Persada University } \\
\text { Lecturers }\end{array}$ & $\begin{array}{c}\text { Numbers of } \\
\text { Lecturers }\end{array}$ \\
\hline 1. & Google Classroom & 8 \\
\hline 2. & Zoom & 5 \\
\hline 3. & Google Meet & 2 \\
\hline 4. & $\begin{array}{l}\text { Darma Persada University Academic Information System } \\
\text { portal.unsada.ac.id) }\end{array}$ & 8 \\
\hline
\end{tabular}

Table 1. Applications and media used by Darma Persada University lecturers

In addition, researchers found several techniques in teaching English to develop students' grammatical knowledge which is usually conducted by lecturers at Darma Persada University as follow:

1. Filling in the Blank

Literally, to complete a statement by adding information to a space that has been intentionally left empty or blank.

2. Reading Aloud

As the important part of language teaching, reading aloud is the primary pivot connecting reading and oral English training. Reading aloud fluently not only helps to foster reading ability and basic skill, but helps to improve oral expression. 
3. Asking and Answering Question

Being able to ask and answer questions is an important part of teaching and learning. Questions may be asked for the purpose of testing student's knowledge.

4. Picture Describing

Describing Picture Strategy is a good activity to improve students' English speaking skill. A picture description is an ideal way of practicing your English vocabulary in all sorts of fields.

5. Drilling

At its simplest, drilling means listening to a model, provided by the teacher, or a tape or another student, and repeating what is heard. This is a repetition drill, a technique that is still used by many teachers when introducing new language items to their students.

6. Presentation

Asking students to give presentations has the following advantages, namely: 1) It gives the presenting student a good opportunity to practice unaided speaking. 2) It gives the other students good listening practice, and 3) It increases the presenting student's confidence when using English.

From all 8 lecturers who taught in one class, the researcher found that the number of lecturers who used these techniques are as follow:

\begin{tabular}{|l|l|l|}
\hline No. & Techniques in teaching English & Numbers of Lecturers \\
\hline 1. & Filling in the blank & 3 \\
\hline 2. & Reading aloud & 3 \\
\hline 3. & Answering questions & 2 \\
\hline 4. & Picture describing & 1 \\
\hline 5. & Drilling & 1 \\
\hline 6. & Presentation & 1 \\
\hline
\end{tabular}

Table 2. Techniques in teaching English used by Darma Persada University lecturers

Based on the observation conducted, the researchers noted that the lecturers of Darma Persada University always tried to speak English during the teaching process as the language of instruction. If there were words that were difficult for students to understand, the lecturers translated them into Indonesian. The lecturers also always asked students to try to answer questions in English. The lecturers also corrected students' pronunciation in a conversation or simple question and answer session as well as explaining and correcting simple grammar mistakes made by students. The lecturers gave explanation on the subject matter firstly word for word, and they taught the grammar of sentence structure only casually. The students were not required to memorize grammar formulas, but the main thing was that students could pronounce the language well.

Second, the researchers noted that the English teaching methods applied by lecturers in Darma Persada University are as follows:

1. Communicative Language Teaching

A communicative approach is an approach that aims to make communicative competence the goal of language learning, as well as developing procedures for learning four language skills (listening, reading, speaking, and writing). Communicative Language Teaching (CLT) is an approach to teaching foreign languages that emphasizes the concept of interaction, both in the process and in the objectives of the learning process.

The communicative approach in language learning emphasizes mastery of language skills. The purpose of language learning according to this approach is factual communication, where students can use foreign languages as a means of communication. In other words, the aim of this approach is for students to have the competence to communicate in the language they learn in various social situations.

2. Grammar Translation Method

This method is the oldest method in the world of foreign language learning. The method emphasizes mastery of grammar. Besides, there are also translations used to teach 
vocabulary. The lecturers taught material about grammar using formulas and used language translation when teaching reading, writing, and vocabulary in English. They stimulated students to speak up, asked them to make up their own sentences, correct their pronunciation, and so on.

3. Audio Lingual Method

Audio Lingual Method is one method that is believed to be effective in making students learn English quickly. Students are taught a language like they were in infancy. The method is that the teacher practices a short dialogue, even if the meaning cannot be translated by the students. The teacher gives instructions to students to follow the dialogue, then the students guess the meaning of the dialogue from the expressions, poses, and various things that are practiced by the teacher.

Based on the findings, the researchers noted that lecturers of Darma Persada University mostly used the Communicative Language Teaching (CLT) method in teaching in class. As previously discussed, researchers found that most lecturers used English to communicate with students. This is in accordance with the purpose of using the CLT method; students could use language as a tool to communicate and express something. The lecturers emphasized more on students how to use language, not just teaching students about the language being learned. However, the CLT method was not automatically applied by Darma Persada University lecturers in all contexts of teaching English. In classroom situations where the student's goal is to master certain aspects of English, for example TOEFL preparation, the teaching learning process is more Grammar-based Translation Method. The GTM method is more appropriate in the classroom to teach grammar because it helps students understand language easily. GTM allows teachers and students to use their mother tongue and target language. Mother tongue is used to explain the lesson, so that students are more confident and not confused in learning the target language.

\section{Conclusion}

The purposes of this research were to analyze the methods of teaching English via online learning system used by lecturers in Darma Persada University, and the media used by the lecturers in teaching English via online learning system. The results showed that the lecturers used media such as Google Classroom, Zoom Meeting, and Google Meet. Based on the observation conducted, the researchers noted that the lecturers of Darma Persada University always try to speak English during the teaching process. Based on the observation's findings, the researchers found that the English teaching method applied by the lecturers are Communicative Language Teaching, Grammar Translation Method, and Audio Lingual Method. The researchers found some techniques in teaching English to develop students' grammatical knowledge which is usually done by lecturers at the Darma Persada University, such as fill in the blank, reading aloud, answering questions, picture describing, drilling and presentation.

This study recommends that lecturers should look at situations when students seem to have difficulty grasping the points of what they have explained using English. Lecturers must realize that students have different preferences in learning, so that lecturers need to improve various strategies for learning English in their class if the strategies are not successfully applied to students.

\section{References}

Chandrawati, Sri Rahayu. (2010). Utilization of E-learning in Learning. No. 2 Vol. 8. http://jurnal.untan.ac.id/

Crystal, D. (1997). English as a Global Language. (p. 12). Cambridge: Cambridge University Press. 
Dhawan, S. (2020). Online Learning: A Panacea in the Time of COVID-19 Crisis. Journal of Educational Technology Systems, Vol. 49, No. 1, pp. 5-22. https://journals.sagepub.com/doi/pdf/10.1177/0047239520934018

Febrianto, P. T., Mas'udah, S., \& Megasari, L. A. (2020). Implementation of Online Learning during the Covid-19 Pandemic on Madura Island, Indonesia. International Journal of Learning, Teaching and Educational Research, Vol. 19, No. 8, pp. 233-254. https://doi.org/10.26803/ijlter.19.8.13

Giatman, M., Siswati, S., Basri, I. Y., (2020). Online Learning Quality Control in the Pandemic Covid-19 Era in Indonesia. Journal of Nonformal Education, Vol. 6, No. 2, pp. 168$\underline{175 .}$

https://journal.unnes.ac.id/nju/i ndex.php/jne

Iskandar dan Dadang Sunendar (2011). Strategi Pembelajaran Bahasa, (p. 12). Bandung: Remaja Rosdakarya.

Kaplan, R.B. (2000). Why is English a Global Language? Problems and Perplexities. In H.W. Kam and C. Ward (Eds). (p. 12). Language in the Global Context: Implications for The Language Classrooms. Singapore: SEAMEO RELC

Pido, Nur Wahidah, Erliana Dewi. (2019). English Teaching Method Applied by Teachers in MTS Negeri Model Limboto. ISSN 2442-8965 \& E ISSN 2442-8973 Volume 4 Nomor 1Februari 2019.

Riesky (2013). How English Teachers Deal With Teaching Difficulties in Their Teaching Practicum. Indonesian Journal of Applied Linguistics, Vol. 2 No. 2, January 2013, pp. 250-261.

Soetomo.(1993). Dasar-dasar Interaksi Belajar Mengajar. (p. 12). Surabaya: Usaha Nasional. 